\title{
INTERGOVERNMENTAL ORGANISATIONS AND ECONOMIC FREEDOM: WISE TECHNOCRATS OR BLACK HELICOPTERS?
}

\author{
Ryan H. Murphy*
}

\begin{abstract}
This article explores the relationship between country membership in major intergovernmental organisations and economic freedom. While it makes no claims to have found any broad theoretically bound, robust causal mechanism, baseline fixed effects models establish relationships amongst economic freedom and membership in the EU, NATO, WTO, UN, OECD, World Bank, and IMF. Though the results are not simple, the strongest findings are negative relationships with the UN, IMF, and WTO, and positive relationships with the World Bank and possibly the EU.
\end{abstract}

JEL codes: F50, F53, P48.

Keywords: economic freedom; economic institutions; European Union; IMF; NATO; OECD; United Nations; World Bank; World Trade Organization.

\section{Introduction}

How does membership in intergovernmental organisations affect the quality of institutions? According to certain elements of the populist right, the situation is dire: Here Come the Black Helicopters (Morris and McGann 2012), Global Tyranny... Step by Step (Jasper 1992). Fear of intergovernmental organisations is perhaps even more pervasive amongst the populist left, although for entirely different reasons (Chomsky 1999; Klein 2007). While the conspiratorial thinking implicit in this literature is dismissed by the ivory tower, it nonetheless constitutes a falsifiable hypothesis. Whereas disproving pure conspiracy theories is intractable, social scientists have accessible data to test the idea that intergovernmental organisations have a detrimental effect on institutional quality. Beyond the broad strokes of the macro question of intergovernmental organisations, the issue is also highly relevant to Britain's referendum on its membership of the European Union (EU) to be held on 23 June 2016.

This article concludes that international institutions have, at best, a mixed effect on economic institutions. It measures the effect of membership in eight intergovernmental organisations in fixed effects regressions. The identification method is hardly unassailable, but even if all the correlations measured are spurious, the alternative explanations are, by and large, unsupportive of the position that joining most intergovernmental organisations is a harbinger of liberty, growth, and prosperity. The results are not uniform, but the interpretation remains disturbing. For example, under a reasonable baseline specification, membership in the World Trade Organization is detrimental. While findings regarding, for example, membership in the EU are more positive, the negative impact of intergovernmental organisations on government involvement in the economy goes some way to support the 'Black Helicopters' interpretation, albeit in less paranoid terms.

\footnotetext{
* Research Assistant Professor, the O'Neil Center for Global Markets and Freedom, Southern Methodist University, Dallas, Texas. Email: rhmurphy@smu.edu
} 
Other literature has attempted to measure the impact of membership in intergovernmental organisations on institutions (e.g. Rose 2004; Haughton 2007; Lejour and de Mooij 2005; Zurn 2000). ${ }^{1}$

Specific mechanisms are discussed in section 2. The associations may be direct (stipulations regarding trade), indirect, or spurious - though spurious in an interesting way. This article measures institutions in this context in terms of economic freedom. It uses the measure of economic freedom employed by Hall et al. (2011) and Tarabar and Young (2014), which has been shown to rigorously relate to growth (de Haan et al. 2006) and has been extensively used elsewhere to study a variety of issues (see Hall and Lawson 2014).

The layout of this article is as follows. Section 2 introduces the data and method employed in the article. Many caveats must be stated regarding the robustness of what could be found. Section 3 presents the results; there were certain unforeseen difficulties in applying the described method to the data. Section 4 concludes.

\section{Data and model}

This article employs fixed effects regressions with controls for logged real GDP per capita from World Development Indicators and the Polity IV index (Marshall et al. 2014) to assess the relationships between membership in intergovernmental organisations and economic freedom. ${ }^{2}$ A simple membership dummy and the natural log of the number of years as a member are simultaneously employed. Economic Freedom, the dependent variable, is measured by the Economic Freedom of the World (EFW) index (Gwartney et al. 2015). Because the time dimension of the question is more salient, the chain-linked version of the economic freedom index was employed. The data set includes the years 1970-2013, with countries and years dictated primarily by EFW, though at times the Polity IV and GDP data also act as binding constraints. Table 1 provides descriptive statistics of all data, and Table 2 provides the correlation matrix of the membership dummies.

Table 1: Descriptive statistics

\begin{tabular}{|c|c|c|c|c|c|}
\hline Variable & obs & mean & std & $\min$ & $\max$ \\
\hline Economic Freedom & 4,572 & 6.12 & 1.31 & 1.78 & 9.15 \\
\hline EU Membership & 5,412 & 0.12 & 0.33 & 0 & 1 \\
\hline Log Years EU & 5,412 & 0.28 & 0.85 & 0 & 3.76 \\
\hline UN Membership & 5,412 & 0.96 & 0.20 & 0 & 1 \\
\hline Log Years UN & 5,412 & 3.06 & 1.22 & 0 & 4.22 \\
\hline WTO Membership & 5,412 & 0.77 & 0.42 & 0 & 1 \\
\hline Log Years WTO & 5,412 & 2.37 & 1.55 & 0 & 4.19 \\
\hline NATO Membership & 5,412 & 0.15 & 0.36 & 0 & 1 \\
\hline Log Years NATO & 5,412 & 0.50 & 1.24 & 0 & 4.16 \\
\hline OECD Membership & 5,412 & 0.21 & 0.41 & 0 & 1 \\
\hline Log Years OECD & 5,412 & 0.67 & 1.32 & 0 & 3.95 \\
\hline \multicolumn{6}{|l|}{ World Bank } \\
\hline Membership & 5,412 & 0.91 & 0.28 & 0 & 1 \\
\hline \multicolumn{6}{|l|}{ Log Years World } \\
\hline Bank Membership & 5,412 & 3.06 & 1.15 & 0 & 4.22 \\
\hline IMF Membership & 5,412 & 0.92 & 0.27 & 0 & 1 \\
\hline Log Years IMF & 5,412 & 3.11 & 1.11 & 0 & 4.22 \\
\hline \multicolumn{6}{|l|}{ Logged GDP per } \\
\hline capita & 4,850 & 8.11 & 1.63 & 4.96 & 11.36 \\
\hline Polity IV & 4,964 & 2.42 & 7.31 & -10 & 10 \\
\hline
\end{tabular}


Table 2: Correlation matrix of intergovernmental dummy variable

\begin{tabular}{lllllll}
\hline & EU & UN & WTO & NATO & OECD & Wld Bk \\
EU & 1.00 & & & & & \\
UN & 0.07 & 1.00 & & & & \\
WTO & 0.19 & 0.14 & 1.00 & & & \\
NATO & 0.69 & 0.08 & 0.22 & 1.00 & 1.00 & \\
OECD & 0.61 & 0.03 & 0.29 & 0.72 & 0.13 & 0.00 \\
World Bank & 0.11 & 0.56 & 0.38 & 0.13 & 0.12 & 0.12 \\
IMF & 0.11 & 0.59 & 0.37 & 0.12 & & \\
\hline
\end{tabular}

All intergovernmental organisations that had a sufficient number of countries and variation in joining dates were included, for a total of eight. There are many other intergovernmental organisations, but none possessed the statistical properties necessary for the analysis. For example, the Latin American Integration Association has only 13 members and the Shanghai Cooperation Organisation has only six. Those intergovernmental organisations which were included are the European Union (EU), the Organisation for Economic Co-operation and Development (OECD), the United Nations (UN), the North Atlantic Treaty Organization (NATO), the World Bank, and the World Trade Organization (WTO). ${ }^{3}$

With year and country fixed effects, the method employed has some semblance to identification, but causality is not established. What is of interest is that these estimates often achieve statistical significance despite the fixed effects and high degree of multicollinearity, as exhibited in the correlation matrix (see Table 2). It is not simply the direct or indirect effects of membership in these organisations which is interesting, but also what the membership may be endogenous to. Because the regression analysis finds large negative effects, perhaps the magnitude of the effects is not believable. However, what membership signals about a country is almost as interesting as the raw effects of membership. Moreover, in the presence of year and country fixed effects, with the character of the government and the level of development controlled for, there are only so many concrete, tangible variables that membership can be endogenous to.

Still, concretising possible mechanisms provides important guidance for interpreting the results in section 3. The direct effects include, for example, the quasi-requirement of NATO members to spend at least 2 per cent of their GDP on the military, sanctions imposed by the WTO, or conditions imposed by the IMF for its loans. The EU, amongst other things, creates a significant free trade area, although the overall effect of the EU may be to 'flatten' the institutional differences amongst the countries. For instance, Estonia had to raise tariffs up from zero when it prepared to join (Weber and Taube 2000). Intergovernmental organisations may also ensconce bad governments in power, ultimately acting counterproductively despite ostensible improvements in policy (Easterly 2014). Indirectly, membership in these organisations may influence the ideology or perceptions of government officials or opinion leaders of the country. Another indirect mechanism may be the mimetic isomorphism amongst countries fuelled by membership (cf. Frumkin and Galaskiewicz 2004).

Alternatively, findings may be considered statistical artefacts. Membership in NATO during the Cold War signalled allegiance to the United States and a preference for the mixed market economy over socialism. Countries that wish to become more open to world markets may feel incentivised to join any or all of these organisations. Ultimately, in the absence of a better method of identification, the results are susceptible to these or similar speculations and counter-arguments related to endogeneity. 
However, the regression results can give us an idea of what joining these organisations may portend for the future trajectory of economic freedom within a given country. Even if it is accepted that the lack of a firm theoretical foundation of the statistical tests limits our confidence in the external validity of the results, at worst these estimations provide a basis for historical interpretation of the path of economic freedom for the in-sample countries historically. ${ }^{4}$ And that is not a trivial matter; what of the recent history of institutional quality, economic policy, and the effects of membership in the European Union? Regardless of what is driving the results, these issues are relevant to the debate about Britain's possible exit from the EU ('Brexit') and to the source of the disagreement amongst pro-market groups within the UK (The Economist 2016; Ridley 2016). Thus, even if these regression results are viewed with all possible scepticism regarding causality and endogeneity, they still amount to findings that should colour our views regarding intergovernmental organisations and economic freedom.

\section{Results}

In this section, the effects of the intergovernmental organisations on the Economic Freedom of the World index are estimated. Table 3 provides baseline regression results. Regression (1) employs no year fixed effects and no country fixed effects. Regression (2) employs only year fixed effects, and Regression (3) employs only country fixed effects. Regression (4) employs both country and year fixed effects and is considered to give the main results for this article. Results for the control variables are unreported but are on the RHS in all regressions along with robust standard errors. One significant issue arose regarding the implementation of the model. There are only seven countries that did not join the World Bank the same year they joined the IMF: Croatia, Barbados, Malta, Poland, Slovenia, and Czech Republic/Slovakia. None of these countries has complete data for all control variables plus EFW. This means there is perfect multicollinearity for measuring membership (though not years of membership) for simultaneously the World Bank and the IMF. To address this, in the baseline regressions the IMF dummy is omitted.

A 0.25 standard deviation change in EFW is 0.328 . The absolute value of many of the coefficients in Regression (4) is within the vicinity of this. The dummy for World Bank membership is minus 1.18, almost a full standard deviation, but the negative sign is mitigated by two factors. One is that the coefficient for logged years of membership in the World Bank is 0.914 , so relatively quickly the net effect is positive. The second is that the dummy for World Bank membership is really a dummy for the effect of membership in the World Bank but also in the IMF; in this one case there are literally no data for distinguishing the effect of one from the other.

To summarise the results, with any statistically insignificant coefficient to zero rounded down for simplicity's sake, the effect of the EU is borderline positive, the effects of the UN, WTO, and IMF are negative, the effects of NATO and the World Bank are ambiguous (because the signs of the log of years and membership dummy coefficients conflict even though both are statistically significant), and the OECD has no statistically significant effect. The dummy variable for the UN is statistically significant despite being equal to one in 96 per cent of observations. ${ }^{5}$ The results for WTO membership, the log of years of NATO membership, World Bank membership, and the log of years of World Bank membership are most robust across the four specifications.

Figures A1-7 rectify the ambiguities and make the point more clearly by graphing the two effects over time (using both point estimates for all variables, even if they are statistically insignificant). The 
Table 3: Baseline regression results

\begin{tabular}{|c|c|c|c|c|}
\hline & (1) & (2) & (3) & (4) \\
\hline \multirow[t]{2}{*}{ EU Membership } & $-0.125^{*}$ & $0.105^{*}$ & 0.181 & $0.241 *$ \\
\hline & $(0.076)$ & $(0.063)$ & $(0.145)$ & $(0.123)$ \\
\hline EU Membership & $0.110 * * *$ & -0.037 & 0.002 & -0.024 \\
\hline Logged Years & $(0.026)$ & $(0.023)$ & $(0.074)$ & $(0.069)$ \\
\hline \multirow[t]{2}{*}{ UN Membership } & $-0.640 * * *$ & $-0.594 * * *$ & $-0.861 * * *$ & -0.215 \\
\hline & $(0.173)$ & $(0.104)$ & $(0.296)$ & $(0.302)$ \\
\hline UN Membership & -0.004 & $-0.032 * *$ & -0.153 & $-0.364 * * *$ \\
\hline Logged Years & $(0.019)$ & $(0.016)$ & $(0.165)$ & $(0.150)$ \\
\hline \multirow{2}{*}{ WTO Membership } & $-0.118^{*}$ & $-0.162 * * *$ & $-0.365 * *$ & $-0.299 * *$ \\
\hline & $(0.064)$ & $(0.057)$ & $(0.155)$ & $(0.147)$ \\
\hline WTO Membership & $0.095^{* * *}$ & $0.054 * * *$ & $0.175^{* *}$ & 0.021 \\
\hline Logged Years & $(0.017)$ & $(0.015)$ & $(0.083)$ & $(0.076)$ \\
\hline \multirow[t]{2}{*}{ NATO Membership } & $1.253 * * *$ & $0.352 * * *$ & 0.237 & 0.603 *** \\
\hline & $(0.134)$ & $(0.093)$ & $(0.253)$ & $(0.230)$ \\
\hline NATO Membership & $-0.442 * * *$ & $-0.134 * * *$ & $-0.187 *$ & $-0.190 *$ \\
\hline Logged Years & $(0.040)$ & $(0.029)$ & $(0.101)$ & $(0.100)$ \\
\hline \multirow[t]{2}{*}{ OECD Membership } & $-0.607 * * *$ & 0.048 & 0.118 & 0.266 \\
\hline & $(0.114)$ & $(0.084)$ & $(0.224)$ & $(0.206)$ \\
\hline OECD Membership & $0.169^{* * *}$ & $0.046^{*}$ & -0.001 & -0.084 \\
\hline Logged Years & $(0.038)$ & $(0.027)$ & $(0.111)$ & $(0.110)$ \\
\hline \multirow[t]{2}{*}{ World Bank Membership } & $-1.600 * * *$ & $-0.826^{* * *}$ & $-1.506 * * *$ & $-1.176^{* * *}$ \\
\hline & $(0.222)$ & $(0.219)$ & $(0.309)$ & $(0.290)$ \\
\hline World Bank Membership & $0.296 * * *$ & $0.430 * * *$ & $0.723 * *$ & $0.914 * * *$ \\
\hline Logged Years & $(0.059)$ & $(0.040)$ & $(0.326)$ & $(0.228)$ \\
\hline IMF Membership & $0.220 * * *$ & $-0.246^{* * *}$ & 0.223 & $-0.459 * * *$ \\
\hline Logged Years & $(0.062)$ & $(0.044)$ & $(0.312)$ & $(0.258)$ \\
\hline Year FE? & $\mathrm{N}$ & $\mathrm{Y}$ & $\mathrm{N}$ & $\mathrm{Y}$ \\
\hline Country FE? & $\mathrm{N}$ & $\mathrm{N}$ & $\mathrm{Y}$ & $\mathrm{Y}$ \\
\hline $\mathrm{R}^{2}$ & 0.517 & 0.618 & 0.499 & 0.572 \\
\hline $\mathrm{n}$ & 4,124 & 4,124 & 4,124 & 4,124 \\
\hline
\end{tabular}

$*=$ confidence at $90 \% ; * *=$ confidence at $95 \% ; * * *=$ confidence at $99 \%$.

Robust standard errors were employed. All regressions control for Polity IV and logged real GDP per capita. IMF Membership omitted due to perfect multicollinearity.

results from Table 3 may be more clearly understood in terms of these figures. After 20 years, there are positive effects from the EU and the World Bank, negative effects from the UN and the IMF, minute negative effects from the WTO, and approximately zero effects from NATO and the OECD. But the question of the overall effect of membership in intergovernmental organisations remains unanswered.

This is addressed with a counterfactual of what economic freedom would look like in the United States if it had not been a member of any of these organisations (or had not been the type of country that self-selects into membership, etc. This ignores EU membership as well). The long-run effects of the intergovernmental organisations are extreme and negative as applied to the United States. The point estimates actually slightly eclipse the maximal value of ten at the turn of the millennium. The effect also grows very slowly, from minus1.23 in 1970 to minus 1.47 in 2013 . This suggests the long-run impact of the organisations may be large.

There remain two concerns regarding the results. The first is that we should at least try to separate the effect of the dummy for the IMF and for the World Bank. Perfect multicollinearity can be avoided by omitting variables, which I performed despite the omitting variable bias. These regressions can be found in Table 4. Besides the explicitly noted differences, the specifications are otherwise identical to 
Regression (4). Regression (5) removes the World Bank dummy variable, Polity IV, and the log of output per capita. Under those conditions, IMF has a negative, statistically significant effect.

Regression (6) includes the log of output per capita and Polity IV. This is, in practice, identical to the regression run in Regression (4), with the effect ascribed to the IMF instead of the World Bank.

Regression (7) removes Polity IV and adds back in the World Bank dummy, and in this instance all variables lose significance. ${ }^{6}$ Note also that the combined effect of the IMF and the World Bank dummies in Regression (7) are not too distant from the effect of the World Bank dummy alone in Regression (4).

The second issue is interpretation. Perhaps these intergovernmental organisations encourage government spending (as in requiring governments to invest in human capital as a condition of receiving IMF loan guarantees) or increase standards of product market regulation (as in the EU), but one may think that they should still have a positive impact on freedom to trade internationally (Area 4 in EFW). This was tested in Table 5. Regression (8) is the same as Regression (4) except that it replaces the EFW index with freedom to trade internationally. Regressions (9)-(12) break it down further to the four components of Area 4: 4A (tariffs), 4B (regulatory trade barriers), 4C (black market exchange rates), and 4D (controls of the movement of capital and people).

If we evaluate Regression (8) as we did with Regression (4), the OECD has contradictory, ambiguous effects. The World Bank and the EU have positive effects. The IMF has negative effects. The WTO does not have statistically significant effects and has possibly detrimental effects on 4D. The UN does not have statistically significant effects. Regressions (10) and (12) omit the World Bank membership dummy due to further perfect multicollinearity caused by the reduction in sample size.

If we take all the results together in the context of the Brexit, the effect of membership in the European Union remains unclear. The overall effect on economic freedom is contingent on specification, and no specification yields especially strong results. There may be more concrete answers regarding its effect on freedom to trade, however. Scores for tariffs, regulatory trade barriers,

Table 4: Omitting variables to include IMF dummy

\begin{tabular}{|c|c|c|c|}
\hline & (5) & (6) & (7) \\
\hline IMF Membership & $\begin{array}{l}-0.835 * * * \\
(0.292)\end{array}$ & $\begin{array}{c}-1.176^{*} \\
(0.191)\end{array}$ & $\begin{array}{l}-0.351 \\
(0.625)\end{array}$ \\
\hline IMF Membership & 0.179 & $-0.459 * * *$ & 0.158 \\
\hline Logged Years & $(0.275)$ & $(0.011)$ & $(0.372)$ \\
\hline World Bank Membership & & & $\begin{array}{c}-0.557 \\
(0.529)\end{array}$ \\
\hline Include World Bank Membership? & $\mathrm{N}$ & $\mathrm{N}$ & $\mathrm{Y}$ \\
\hline Include Polity IV? & $\mathrm{N}$ & $\mathrm{Y}$ & $\mathrm{N}$ \\
\hline Include LnRGDPcap? & $\mathrm{N}$ & $\mathrm{Y}$ & $\mathrm{Y}$ \\
\hline Include all other controls? & $\mathrm{Y}$ & $\mathrm{Y}$ & $\mathrm{Y}$ \\
\hline Include all fixed effects? & $\mathrm{Y}$ & $\mathrm{Y}$ & $\mathrm{Y}$ \\
\hline $\mathrm{R}^{2}$ & 0.306 & 0.572 & 0.569 \\
\hline $\mathrm{n}$ & 4,572 & 4,124 & 4,358 \\
\hline
\end{tabular}

$*=$ confidence at $90 \% ; * *=$ confidence at $95 \% ; * * *$ confidence at $99 \%$.

Robust standard errors were employed. These regressions are otherwise identical to Regression (4), found in Table 3. 
Table 5: Freedom to trade internationally

\begin{tabular}{|c|c|c|c|c|c|}
\hline \multirow[t]{2}{*}{ LHS } & EFW Area 4 & $4 \mathrm{~A}$ & 4B & $4 \mathrm{C}$ & $4 \mathrm{D}$ \\
\hline & (8) & (9) & (10) & (11) & (12) \\
\hline \multirow[t]{2}{*}{ EU Membership } & $0.844 * * *$ & $0.700 * * *$ & $0.623 * * *$ & -0.164 & $0.928^{* *}$ \\
\hline & $(0.241)$ & $(0.244)$ & $(0.152)$ & $(0.296)$ & $(0.466)$ \\
\hline EU Membership & -0.272 & $-0.522 * * *$ & $-0.372 * * *$ & $-0.295^{* *}$ & $-0.637 * * *$ \\
\hline Logged Years & $(0.170)$ & $(0.183)$ & $(0.111)$ & $(0.151)$ & $(0.162)$ \\
\hline \multirow[t]{2}{*}{ UN Membership } & -0.937 & -0.302 & -0.459 & $-1.752 *$ & $-2.781^{*}$ \\
\hline & $(0.599)$ & $(0.574)$ & $(0.557)$ & $(0.955)$ & $(1.544)$ \\
\hline UN Membership & -0.311 & $-0.840 * *$ & -0.251 & -0.225 & 0.302 \\
\hline Logged Years & $(0.282)$ & $(0.381)$ & $(0.414)$ & $(0.494)$ & $(1.093)$ \\
\hline \multirow[t]{2}{*}{ WTO Membership } & -0.353 & 0.197 & 0.211 & -0.026 & $-0.619 *$ \\
\hline & $(0.293)$ & $(0.388)$ & $(0.336)$ & $(0.449)$ & $(0.342)$ \\
\hline WTO Membership & 0.072 & 0.206 & 0.325 & -0.162 & -0.506 \\
\hline Logged Years & $(0.145)$ & $(0.212)$ & $(0.482)$ & $(0.242)$ & $(0.546)$ \\
\hline \multirow[t]{2}{*}{ NATO Membership } & $0.752 *$ & 0.648 & $0.337 *$ & 0.503 & 0.428 \\
\hline & $(0.448)$ & $(0.448)$ & $(0.192)$ & $(0.633)$ & $(0.347)$ \\
\hline NATO Membership & -0.406 & 0.013 & $-0.320 * *$ & -0.050 & -0.071 \\
\hline Logged Years & $(0.280)$ & $(0.269)$ & $(0.147)$ & $(0.282)$ & $(0.319)$ \\
\hline \multirow[t]{2}{*}{ OECD Membership } & $0.868 * * *$ & $1.545^{* * *}$ & 0.251 & $1.340 * * *$ & 0.146 \\
\hline & $(0.309)$ & $(0.470)$ & $(0.217)$ & $(0.453)$ & $(0.384)$ \\
\hline OECD Membership & $-0.574 * * *$ & $-1.366^{* * *}$ & -0.237 & $-0.965^{* * * *}$ & 0.145 \\
\hline Logged Years & $(0.203)$ & $(0.312)$ & $(0.197)$ & $(0.280)$ & $(0.397)$ \\
\hline \multirow[t]{2}{*}{ World Bank Membership } & -0.677 & 0.024 & $\dagger$ & 1.409 & $\dagger$ \\
\hline & $(1.105)$ & $(0.606)$ & & $(1.082)$ & \\
\hline World Bank Membership & $1.370^{* *}$ & 3.181 & 0.581 & 0.576 & 2.925 \\
\hline Logged Years & $(0.645)$ & $(2.492)$ & $(1.077)$ & $(1.183)$ & $(2.423)$ \\
\hline IMF Membership & $-1.326^{* * *}$ & -4.066 & -0.023 & 0.636 & -1.933 \\
\hline Logged Years & $(0.658)$ & $(2.561)$ & $(1.027)$ & (1.192) & $(2.265)$ \\
\hline Year FE? & $\mathrm{Y}$ & $\mathrm{Y}$ & $\mathrm{Y}$ & $\mathrm{Y}$ & $\mathrm{Y}$ \\
\hline Country FE? & $\mathrm{Y}$ & $\mathrm{Y}$ & $\mathrm{Y}$ & $\mathrm{Y}$ & $\mathrm{Y}$ \\
\hline $\mathrm{R}^{2}$ & 0.479 & 0.026 & 0.556 & 0.217 & 0.425 \\
\hline $\mathrm{n}$ & 4,226 & 3,215 & 1,704 & 4,510 & 1,683 \\
\hline
\end{tabular}

$*=$ confidence at $90 \% ; * *=$ confidence at $95 \% ; * * *=$ confidence at $99 \%$.

$\uparrow$ Variable dropped due to perfect multicollinearity.

EFW, Economic Freedom of the World (Gwartney et al. 2015).

Robust standard errors were employed. All regressions control for Polity IV and logged real GDP per capita. IMF Membership omitted due to perfect multicollinearity.

and controls of the movement of capital and people seem to improve upon entry into the EU, but the net effect is negative relatively quickly for all three. The results imply that EU membership may at first have benefited the UK by promoting free trade, but this is unlikely to hold true in the future. ${ }^{7}$

\section{Conclusion}

Perhaps intergovernmental organisations promote peaceful cooperation amongst countries. Perhaps they are effective in helping coordinate humanitarian aid. But their relationship with the quality of a country's market-oriented institutions appears, broadly speaking, negative. Entangling alliances may in fact be entangling, heralding declines in institutional quality. As for Brexit specifically, the overall effect of the EU is unclear, but the UK's gains in freedom to trade from the EU have likely at this point been dissipated. 
One great irony is the vociferous populist 'anti-globalisation' protests against the WTO in 1999 in Seattle. Perhaps trade barriers would have been decreased in their absence, but if anything it appears that the WTO is an obstacle to economic liberalisation. Naomi Klein may have had it backwards. There may not be black helicopters on the horizon ready to take away sovereignty and liberty, but there is quite possibly a relationship between membership in these organisations and erosions of economic freedom.

\section{Appendix}

\section{Net effect of intergovernmental organisations on economic freedom}

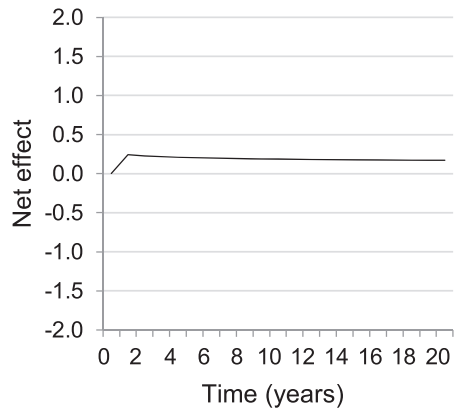

Figure A1: EU.

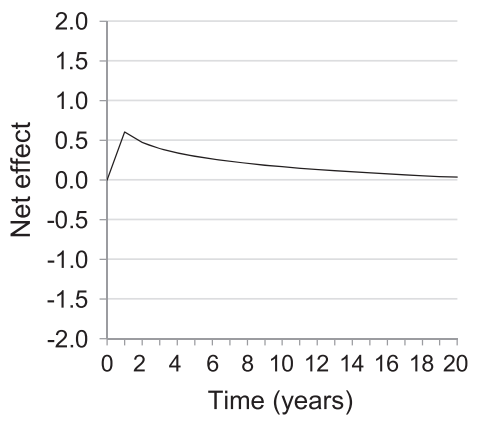

Figure A4: NATO.

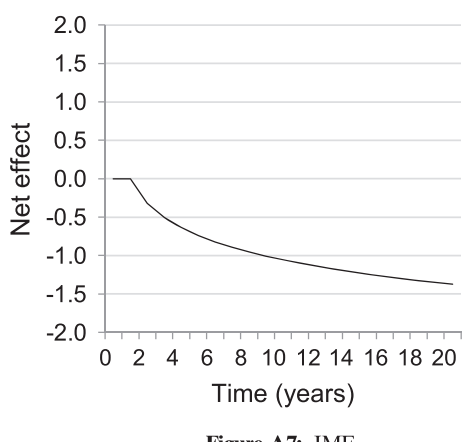

Figure A7: IMF.

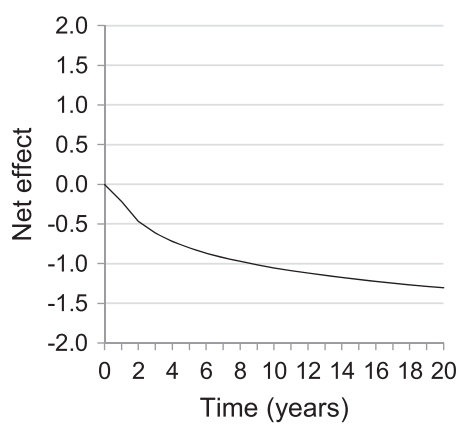

Figure A2: UN.

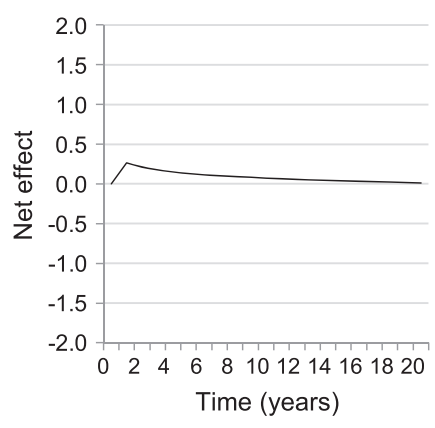

Figure A5: OECD.

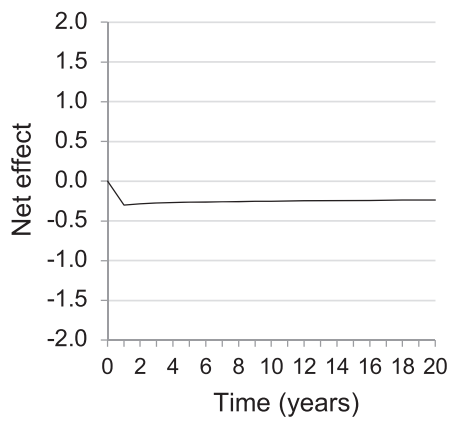

Figure A3: GATT/WTO.

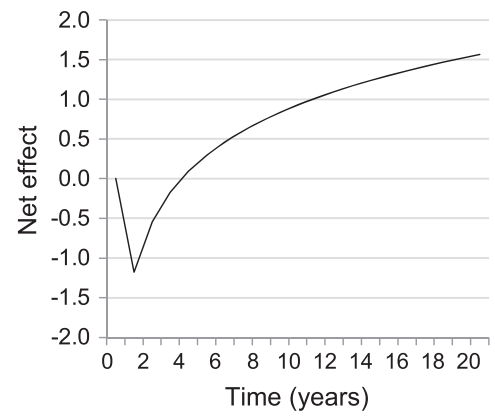

Figure A6: World Bank. 


\section{Notes}

1. See Ikenberry (1998-1999) for an alternative interpretation.

2. It is possible to run this analysis using alternative measures of institutions, including with Polity IV, but economic freedom seems most appropriate given that the political right seems primarily concerned about creeping socialism.

3. Years of entering membership can be found in various online sources: European Union (2015) for the EU, OECD (2015), UN (n.d.), US Department of State (2009) for NATO, IMF (2012), World Bank (n.d.) (the list used was for the International Bank for Reconstruction and Development), and WTO (n.d.). The World Trade Organization's predecessor, the General Agreement on Tariffs and Trade (GATT), was considered to be the same organisation as the WTO.

4. Suppose the mechanism by which the WTO affected economic freedom was its sanctions against tariffs. Then a leadership change and a policy of weakening these sanctions may eliminate its effectiveness in enhancing economic freedom. But since the WTO could hypothetically affect economic freedom through other mechanisms, it would not be clear whether such a development would justify anticipating a change in its impact. Because no deeply defined theory is being tested, out-of-sample predictions may not be expected to be reliable.

5. Omitting the two United Nations variables does not change the sign of any of the other variables of interest. It has only modest impacts on coefficients and $t$-statistics.

6. What would be the following regression in the table, omitting logged output per capita and including Polity IV, could not be performed because of the perfect multicollinearity.

7. The component $4 \mathrm{C}$, black-market exchange rates, shows only negative effects of EU membership, but it is not clear that membership seriously threatens this type of market intervention in the UK specifically.

\section{References}

Chomsky, N. (1999) Profit over People: Neoliberal and Global Order. New York: Seven Stories Press.

de Haan, J., S. Lundstrom and J.-E. Sturm (2006) 'Market-Oriented Institutions and Policies and Economic Growth: A Critical Survey', Journal of Economic Surveys 20(2), 157-91.

Easterly, W. (2014) The Tyranny of Experts: Economists, Dictators, and the Forgotten Rights of the Poor. New York: Basic Books.

The Economist (2016) 'The real danger of Brexit', 27 February. http://www.economist.com/news/leaders/21693584leaving-eu-would-hurt-britainand-would-also-deal-terrible-blow-west-real-danger (accessed 12 April 2016).

European Union (2015) EU Member Countries. http://europa.eu/about-eu/countries/member-countries/ (accessed 30 April 2016).

Frumkin, P. and J. Galaskiewicz (2004) 'Institutional Isomorphism and Public Sector Organisations', Journal of Public Administration Research and Theory 14(3), 283-307.

Gwartney, J., R. Lawson and J. Hall (2015) Economic Freedom of the World. Vancouver, BC: Fraser Institute.

Hall, J. and R. Lawson (2014) 'Economic Freedom of the World: An Accounting of the Literature', Contemporary Economic Policy 32(1), 1-19.

Hall, J., R. Lawson and R. Wogsland (2011) 'The European Union and Economic Freedom', Global Economy Journal 11(3), 1-14.

Haughton, T. (2007) 'When Does the EU Make a Difference? Conditionality and the Accession Process in Central and Eastern Europe', Political Studies Review 5(2), 233-46.

Ikenberry, J. (1998-1999) 'Institutions, Strategic Restraint, and the Persistence of American Postwar Order', International Security 23(3), 43-78.

IMF (International Monetary Fund) (2012) List of Members. https://www.imf.org/external/np/sec/memdir/memdate. htm (accessed 28 January 2016).

Jasper, W. F. (1992) Global Tyranny... Step by Step: The United Nations and the Emerging New World Order. Appleton, WI: Western Islands.

Klein, N. (2007) The Shock Doctrine: The Rise of Disaster Capitalism. New York: Picador.

Lejour, A. and R. A. de Mooij (2005) 'Turkish Delight: Does Turkey's Accession to the EU Bring Economic Benefits?', Kyklos 58(1), 87-120.

Marshall, M., T. Gurr and K. Jaggers (2014) Polity IV Project: Political Regime Characteristics and Transitions 1800-2013. Vienna, VA: Center for Systemic Peace. http://www.systemicpeace.org/polity/polity4.htm (accessed 30 September 2015).

Morris, D. and E. McGann (2012) Here Come the Black Helicopters! UN Governance and the Loss of Freedom. New York: HopperCollins. 
OECD (Organisation for Economic Co-operation and Development) (2015) List of OECD Member Countries - Ratification of the Convention on the OECD. http://www.oecd.org/about/membersandpartners/ list-oecd-member-countries.htm (accessed 30 September 2015).

Ridley, M. (2016) 'Leaving Europe would be a leap into the light', The Times, 22 February. http://www.thetimes.co.uk/ tto/opinion/columnists/article4695987.ece (accessed 12 April 2016).

Rose, A. K. (2004) 'Do We Really Know That the WTO Increases Trade?', American Economic Review 94(1), 98-114.

Tarabar, D. and A.Young (2014) 'Does the European Union Promote Convergence in Economic Freedom?', in J. Cantalou and C. M. Haury (eds), The European Union - Catalyst for Economic Freedom? Brussels: Friedrich Naumann Foundation for Freedom.

UN (United Nations) (n.d.) Member States. http://www.un.org/en/members/ (accessed 30 September 2015).

US Department of State (2009) North Atlantic Treaty. http://www.state.gov/documents/organization/81563.pdf (accessed 30 September 2015).

Weber, R. and G. Taube (2000) 'Estonia Moves toward EU Accession', Finance \& Development 37(3), 28 -31.

World Bank (n.d.) Member Countries. http://www.worldbank.org/en/about/leadership/members (accessed 28 January 2016).

WTO (World Trade Organization) (n.d.) Members and Observers. https://www.wto.org/english/thewto_e/whatis_e/ tif_e/org6_e.htm (accessed 30 September 2015).

Zurn, M. (2000) 'Democratic Governance Beyond the Nation State: The EU and Other Intergovernmental Institutions', European Journal of International Relations 6(2), 183-221. 